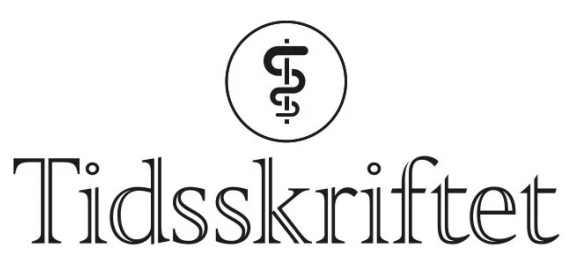

DEN NORSKE LEGEFORENING

\title{
Antistoffrespons hos en familie med covid-19
}

KORT KASUISTIKK

\section{STIAN HENRIKSEN}

Avdeling for mikrobiologi og smittevern Universitetssykehuset Nord-Norge og

Universitetet i Troms $\emptyset$ - Norges arktiske universitet Stian Henriksen er ph.d.-student i virologi, tilknyttet forskningsgruppen Metabolisme og nyremedisin.

Forfatteren har fylt ut ICMJE-skjemaet og oppgir ingen interessekonflikter.

\section{$\varnothing$ ØVIND TRYDAL}

Avdeling for mikrobiologi og smittevern Universitetssykehuset Nord-Norge

Øyvind Trydal er lege i spesialisering i mikrobiologi.

Forfatteren har fylt ut ICMJE-skjemaet og oppgir ingen interessekonflikter.

\section{STEN-EIGIL SIGURDSEN}

Avdeling for mikrobiologi og smittevern Universitetssykehuset Nord-Norge

Sten-Eigil Sigurdsen er overbioingeniør.

Forfatteren har fylt ut ICMJE-skjemaet og oppgir ingen interessekonflikter.

\section{GARTH D. TYLDEN}

Avdeling for mikrobiologi og smittevern Universitetssykehuset Nord-Norge og Universitetet i Troms $\emptyset$ - Norges arktiske universitet Garth D. Tylden er spesialist i medisinsk mikrobiologi og førsteamanuensis. Forfatteren har fylt ut ICMJE-skjemaet og oppgir ingen interessekonflikter.

\section{CHRISTINE HANSSEN RINALDO}

christine.rinaldo@unn.no

Avdeling for mikrobiologi og smittevern

Universitetssykehuset Nord-Norge

og

Universitetet i Troms $\emptyset$ - Norges arktiske universitet

Christine Hanssen Rinaldo er seniorforsker i virologi og professor tilknyttet forskningsgruppen Metabolisme og nyremedisin.

Forfatteren har fylt ut ICMJE-skjemaet og oppgir ingen interessekonflikter. 
Tre av fem personer i en familie utviklet covid-19 etter en utenlandsreise. Med ulike serologiske metoder ble sars-CoV2-antistoff, inkludert nøytraliserende antistoff, påvist hos disse tre 3-4 uker etter symptomstart. Tester fra én leverandør var positive også hos et fjerde familiemedlem, sannsynligvis pga. kryssreaksjon. Gode serologiske tester er avgjørende for å påvise gjennomgått infeksjon og finne plasmadonorer til bruk i covid-19-behandling.

En familie bestående av mor, far og tre voksne barn dro på en ukes skiferie til Sør-Europa. De var alle friske bortsett fra den ene sønnen ( sønn 2), som hadde influensalignende symptomer med feber, sår hals, rhinoré og litt hoste før avreise og de første dagene av ferien. Foreldrene bodde på ett hotellrom og søsknene på et annet. To dager før hjemreise ble datteren syk med redusert allmenntilstand, oppkast og sår hals. Hun fikk etter hvert også feberfølelse, rhinoré, tap av luktesans og hodepine. På grunn av utbredt covid-19 der de ferierte, gikk foreldre og datter straks etter hjemkomst i isolasjon i samme bolig. To dager etter hjemkomst ble nasofarynksprøve fra datteren undersøkt for sars-CoV-2-RNA ved polymerasekjedereaksjon (PCR), men resultatet var negativt. Hun utviklet tørrhoste, og ny prøve tre dager senere var positiv. Familiens sykehistorie er gjengitt i figur 1. 


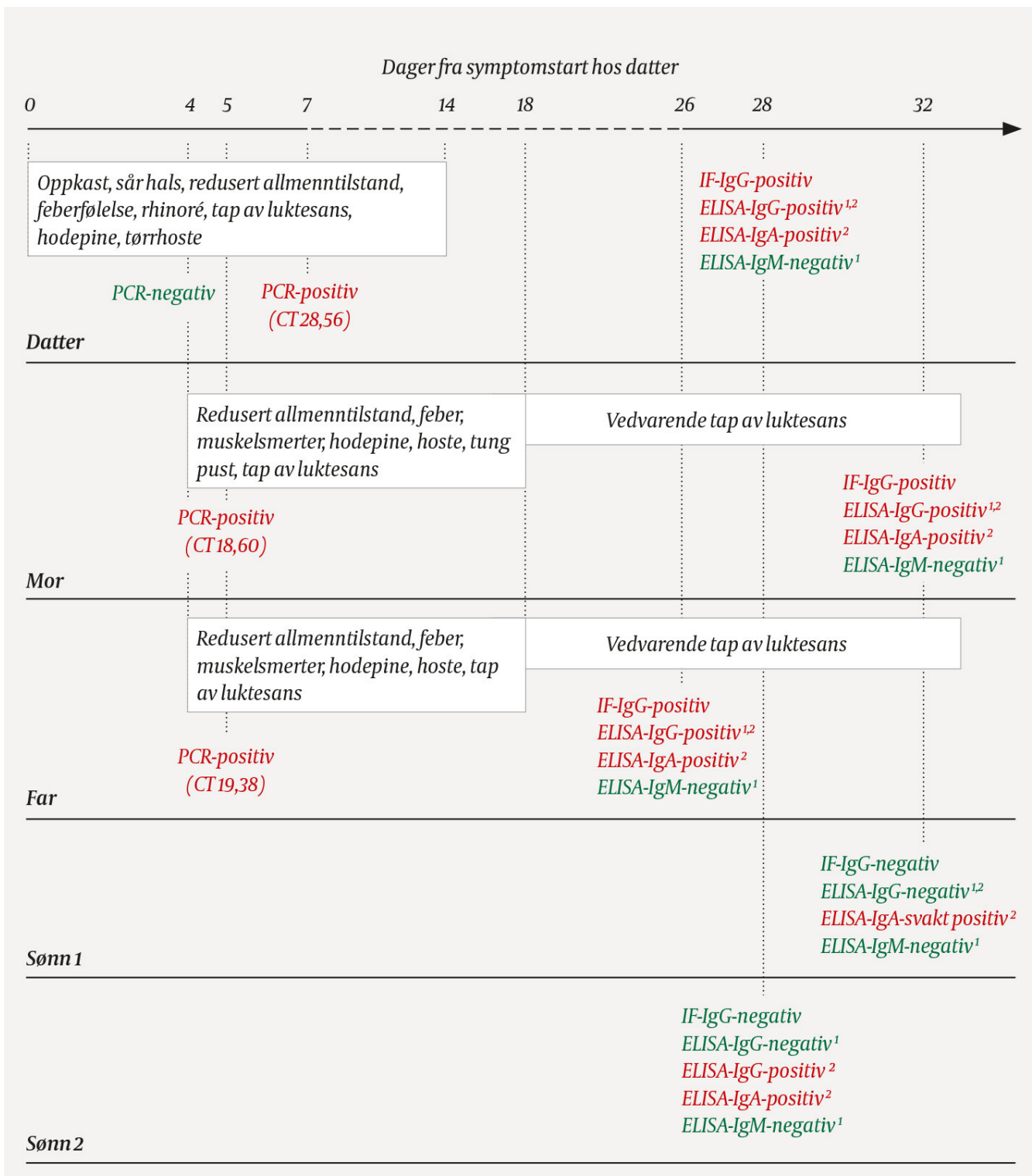

${ }^{1}$ Leverandør1 ${ }^{2}$ Leverandør2

Figur 1 Tidslinje over symptomer og diagnostikk for en familie eksponert for sars-CoV-2. Ved polymerasekjedereaksjon (PCR) kjøres 40 sykluser der mengden virusgenom i prøven fordobles ved hver syklus. Syklusterskel (cycle threshold, CT) er definert som det antall PCR-sykluser som må kjøres før prøven gir et positivt resultat. Dette betyr at prøven med terskelverdi 18,6o hadde høyest mengde virusgenom. ELISA-testen fra leverandør 1 og 2 benytter henholdsvis nukleokapsidprotein og pigg (spike)-protein som antigen.
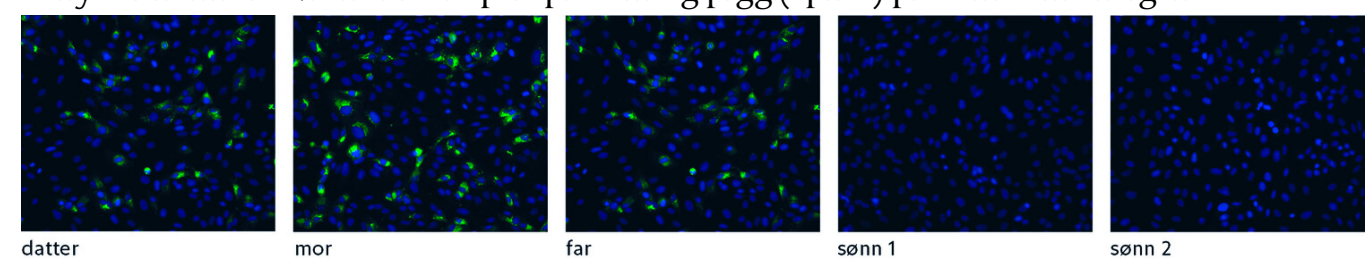

Figur 2 Immunfluorescensfarging (IF) av sars-CoV-2-infiserte celler med serum fra alle fem i familien. Sars-CoV-2-spesifikt IgG kunne påvises i serum fra datter, mor og far ved at infiserte celler fikk grønnfarget cytoplasma. Se også figur 1 for metodeforklaring. To dager etter hjemkomst utviklet også begge foreldrene redusert allmenntilstand med feber, muskelsmerter, hodepine, hoste og etter hvert tap av luktesans. Dagen etter testet begge positivt for sars-CoV-2-RNA. Seks dager etter symptomdebut fikk moren forbigående tung pust og forverring av allmenntilstanden. Mens datteren ble symptomfri etter to uker, 
hadde begge foreldrene fortsatt lett redusert luktesans seks uker etter symptomdebut. De to sønnene hadde ingen symptomer på covid-19 og ble ikke testet, men satt etter hjemkomst i hjemmekarantene.

Blodprøver fra familien inngikk som en del av et valideringspanel på totalt 46 sera. Vi benyttet tre serologiske metoder ramme 1) som tidligere er beskrevet ((1), med mindre modifikasjoner. Indirekte immunfluorescensfarging viste at serum fra foreldrene og datteren, men ikke fra sønnene, inneholdt sars-CoV-2-spesifikt IgG (figur 2). IgG-ELISA (Enzyme-Linked ImmunoSorbent Assay)-tester fra to ulike leverandører bekreftet funn av IgG hos foreldre og datter, men testen fra leverandør 2 påviste dessuten IgG hos sønn 2. En IgA-ELISA-test fra leverandør-2 påviste sars-CoV-2-spesifikt IgA hos alle fem, men IgA-nivået hos sønn 1 var svært lavt. En IgM-ELISA-test fra leverandør-1 kunne ikke påvise sars-CoV-2spesifikt IgM hos noen av familiemedlemmene. Kun de tre PCR-positive familiemedlemmene hadde påvisbart nøytraliserende antistoff.

\section{Ramme 1 Vårt utvalg av metoder for påvisning av antistoff mot sars-CoV-2 (1). Metodene for indirekte immunflourescens og nøytralisering er utviklet ved Universitetssykehuset Nord-Norge.}

Indirekte immunfluorescensfarging påviser tilstedeværelse av sars-CoV-2-spesifikt IgG rettet mot forskjellige virusproteiner (antigen) i infiserte celler. Apenyreceller (Vero-celler) infiseres med sars-CoV-2 og fikseres neste dag. Pasientserum tilsettes. Eventuelle antistoff mot sars-CoV-2-antigen binder til antigen i infiserte celler. Tilsetting av et fluorescerende antistoff mot IgG gjør de infiserte cellene fluorescerende.

Indirekte ELISA (enzyme-linked immunosorbent assay) påviser tilstedeværelse av sars-CoV2-spesifikt antistoff rettet mot ett utvalgt virusantigen. Pasientserum tilsettes en plastbrønn med antigen festet i bunnen. Eventuelle antistoff mot antigenet bindes. Et enzymmerket antistoff mot IgM, IgG eller IgA tilsettes og bindes til det bundne antistoffet. Tilsetting av substrat gir en målbar fargeendring.

Nøytralisasjonstest er gullstandard for påvisning av sars-CoV-2-spesifikke nøytraliserende antistoff av ulike immunglobulinklasser. Pasientserum seriefortynnes, tilsettes sars-CoV-2 og brukes til å infisere Vero-celler. Etter fiksering og indirekte immunfluorescensfarging med antistoff mot sars-CoV-2 estimeres antall infiserte celler. Nøytralisasjonstiter er den fortynningen som reduserer antall infiserte celler med $50 \%$.

\section{Diskusjon}

Hvem som var indekspasienten i familien, er fortsatt usikkert. Ettersom sønn 2 utviklet symptomer før avreise, på et tidspunkt med svært lite sars-CoV-2-smitte i Norge, er det lite sannsynlig at han var indekspasient. Datteren utviklet symptomer mens hun var på ferie, men kan ha debutert med en annen infeksjon. Hun hadde rhinoré, som ikke er så vanlig ved covid-19, hennes første nasofarynksprøve tatt fire dager etter symptomstart var negativ for sars-CoV-2-RNA, og hun smittet tilsynelatende ikke brødrene til tross for tett samvær. Selv om de fleste skiller ut st $\varnothing$ rst mengde virus i $\emptyset$ vre luftveier ved symptomstart (므), er det rapportert om pasienter med negativ første prøve og fluktuerende virusmengde (3). Et negativt PCR-resultat kan i tillegg til lav virusmengde skyldes dårlig utført prøvetaking, lang transporttid eller laboratoriefeil. Det er heller ikke uvanlig at bare noen familiemedlemmer får covid-19. I en studie av 105 familier med covid-19 fant man smitte hos $16,3 \%$ av husstandsmedlemmene og at partnere var mest utsatte (4). Da begge foreldrene testet positivt på PCR før datteren, kan de ha vært indekspasienter. Det kan heller ikke utelukkes at alle tre ble smittet fra kilder på feriestedet. 
Antistoff spiller en sentral rolle i immunforsvarets respons på en virusinfeksjon. Hos de tre familiemedlemmene med PCR-bekreftet covid-19 kunne vi påvise sars-CoV-2-spesifikt IgG, IgA og nøytraliserende antistoff. Vi kunne ikke påvise sars-CoV-2-spesifikt IgM, noe som er interessant da IgM vanligvis påvises før IgG. Det er rapportert at personer med milde symptomer har lavere sars-CoV-2-antistoffnivå enn de med alvorlig sykdom (5), og dette kan ha bidratt til negative resultater. IgA-ELISA gav positive resultater hos alle familiemedlemmene, men sønn 1 var bare svakt positiv. IgA spiller en viktig rolle ved influensa og antas derfor også å spille en rolle ved covid-19. Majoriteten av IgA befinner seg ikke i serum, som er det materialet vi tester, men på slimhinner i øvre luftveier. Vår benyttede IgA-ELISA-test er rapportert å ha høy sensitivitet, men lav spesifisitet (5), og vi tror derfor at de positive IgA-resultatene hos begge sønnene skyldes uspesifikk reaktivitet. IgG-ELISA fra leverandør 2 var positiv hos sønn 2. Leverandøren har opplyst at ELISA-testene kan påvise antistoff mot influensavirus, og kryssreaksjon med antistoff mot humane koronavirus har vært rapportert (5). Den influensalignende sykdommen hos sønn 2 kan derfor ha bidratt til falskt positive resultater for IgA og IgG. Asymptomatisk covid-19 kan imidlertid ikke utelukkes (2) .

Hva betyr disse resultatene for familien? Positiv ELISA og immunfluorescensfarging påviser antigenbindende antistoff og bekrefter gjennomgått infeksjon. Påvisning av nøytraliserende antistoff, derimot, er ut fra erfaring med andre virus, inkludert sars-CoV-1, den beste indikatoren for beskyttende immunitet. Det er fortsatt for tidlig å si noe om hvor lenge immuniteten vil vare. Til tross for manglende kliniske studier er allerede flere covid19-pasienter blitt behandlet med plasma med nøytraliserende antistoff( $\underline{6}$ ).

Sars-CoV-2 ble oppdaget så sent som i januar 2020, og produsenter av diagnostiske tester for covid-19 har utviklet disse på rekordtid. Vår erfaring tilsier at ikke alle kommersielle serologiske tester som tilbys for covid-19-diagnostikk, gir gode nok resultater.

Pasientene har gitt samtykke til at artikkelen blir publisert.

Artikkelen er fagfellevurdert.

\section{LITTERATUR}

1. Kohmer N, Westhaus S, Rühl C et al. Clinical performance of different SARS-CoV-2 IgG antibody tests. J Med Virol 2020; 92: jmv.26145. [PubMed][CrossRef]

2. Eurosurveillance Editorial Team. Updated rapid risk assessment from ECDC on coronavirus disease 2019 (COVID-19) pandemic: increased transmission in the EU/EEA and the UK. Euro Surveill 2020; 25: 2003121.

3. Li Y, Yao L, Li J et al. Stability issues of RT-PCR testing of SARS-CoV-2 for hospitalized patients clinically diagnosed with COVID-19. J Med Virol 2020; 92: 903-8. [PubMed][CrossRef]

4. Li W, Zhang B, Lu J et al. The characteristics of household transmission of COVID-19. Clin Infect Dis 2020; 71: ciaa450. [PubMed][CrossRef]

5. Okba NMA, Müller MA, Li W et al. Severe acute respiratory syndrome coronavirus 2-specific antibody responses in coronavirus disease 2019 patients. Emerg Infect Dis 2020; 26: 1478-88. [PubMed] [CrossRef]

6. Rajendran K, Krishnasamy N, Rangarajan J et al. Convalescent plasma transfusion for the treatment of COVID-19: Systematic review. J Med Virol 2020; 92: jmv.25961. [PubMed][CrossRef]

Publisert: 23. juli 2020. Tidsskr Nor Legeforen. DOI: 10.4045/tidsskr.20.0420

Mottatt 8.5.2020, første revisjon innsendt 3.6.2020, godkjent 19.6.2020.

Publisert under åpen tilgang CC BY-ND. Lastet ned fra tidsskriftet.no 26. april 2023. 